\title{
KETERAMPILAN KOMUNIKASI HIPNOTIC KONSELING
}

\author{
HIMSONADI \\ Institut Agama Islam Hamzan Wadi (IAH) Pancor \\ Email: himson45@gmail.com
}

\begin{abstract}
Counselling communication skills are one of the competencies that must be possessed by a counselling teacher, both verbal and non-verbal communication. The success of counselling is largely determined by the ability of counsellors to master effective counselling communication skills and evidence of mastery of counselling communication skills is manifested in the form of effective communication practices with techniques in the counselling process. In addition to mastering counselling techniques in general, counsellors must have the ability to influence, because the success of counselling can not be separated from the extent to which the counsellor influences the counselee being served. With the ability to influence the counsellor, BK can easily help the counselee. Techniques used by counsellors to influence counselees as offered in this journal, including counsellors must master the principles of hypnosis counselling and can use hypnosis counselling language patterns, both of which can be applied at each individual counselling stage.
\end{abstract}

Keywords: Communication, Counseling and Hypnotic

Abstrak: Keterampilan komunikasi konseling merupakan salah satu kompetensi yang harus dimiliki oleh seorang konselor/guru BK baik komunikasi verbal maupun non verbal. Keberhasilan konseling sangat ditentukan oleh kemampuan konselor/guru BK mengusai keterampilan komunikasi konseling secara efektif dan bukti penguasaan keterampilan komunikasi konseling diwujudkan dalam bentuk praktik berkomunikasi secara efektif dengan tehnik-tehnik dalam suatu proses konseling. Selain menguasi tehnik-tehnik konseling secara umum, konselor/guru BK harus memiliki kemampuan dalam memberi pengaruh, karna keberhasilan konseling tidak terlepas dari sejauhmana konselor/guru BK memiliki pengaruh terhadap konseli yang dialayani. Dengan kemampuan mempengaruhi maka konselor/guru BK bisa dengan mudah dalam memberikan bantuan kepada konseli. Adapun tehnik-tehnik yang digunakan konselor/guru BK untuk mempengaruhi konseli sebagaimana 
yang tawarkan dalam jurnal ini, diantaranya konselor/guru BK harus menguasai prinnsif-prinsif hipnotic counseling serta mampu menggunakan pola bahasa hipnotic counseling, yang mana kedua hal tersebut bisa terapkan pada setiap tahapantahapan konseling individual.

Kata Kunci: Komunikasi, Konseling dan Hipnotic

\section{A. Pendahuluan}

Istilah bimbingan dan konseling sudah tidak asing lagi ditelinga kita, istilah ini sudah sering sekali diungkapkan oleh para pakar ilmuan psikologi maupun para pendidik/guru. Berdasarkan Permendikbud Nomor 111 Tahun 2014. Layanan Bimbingan dan Konseling adalah upaya sistematis, objektif, logis, dan berkelanjutan serta terprogram yang dilakukan oleh konselor atau guru Bimbingan dan Konseling untuk memfasilitasi perkembangan peserta didik/konseli untuk mencapai kemandirian, dalam wujud kemampuan memahami, menerima, mengarahkan, mengambil keputusan, dan merealisasikan diri secara bertanggung jawab sehingga mencapai kebahagiaan dan kesejahteraan dalam kehidupannya. ${ }^{1}$ Mengacu pada pengertian bimbingan dan konseling tersebut diatas sudah jelas

${ }^{1}$ Permendikbud Nomor 111 Tahun 2014 Tentang Bimbingan dan Konseling Pada Pendidikan Dasar dan Menengah, Pasal 1 Ayat 1 bahwa layanan bimbingan dan konseling harus dilaksanakan oleh tenaga yang berkompetensi dalam bidang bimbingan dan konseling yang tidak hanya bermodalkan status akademisi S1 dalam bidang bimbingan dan konseling tapi tidak memiliki kompetensi dalam bidang bimbingan dan konseling. ${ }^{2}$

Bimbingan dan konseling terdiri dari dua suku kata yaitu bimbingan dan konseling, dimana kedua istilah ini bisa digunakan secara mandiri atau masingmasing, istilah bimbingan bisa digunakan oleh siapapun yang mampu memberikan upaya bimbingan kepada orang lain ataupun kepada peserta didik. Namun istilah konseling hanya bisa dipergunakan oleh orang-orang memiliki kualifikasi akademik S1 dalam bidang bimbingan dan konseling serta memiliki kompetensi dalam bidang bimbingan dan konseling. Layanan konseling merupakan bagian utama atau

\footnotetext{
${ }^{2}$ Permendiknas Nomor 27 Tahun 2008 Tentang Standar Kualifikasi Akademik dan Kompetensi Konselor.
} 
bisa juga dikatakan sebagai jantung hubungan guru dengan siswa, hubungan daripada layanan bimbingan dan dokter dengan pasien dan hubungan konseling. Upaya pelaksanaan layanan konselor dengan konseli. Sedangkan konseling juga akan mencakup upaya hubungan membantu yang bukan bimbingan, tetapi upaya bimbingan professional merupakan hubungan tidak mencakup upaya konseling. diluar urusan konteks profesi yang Disinilah beberapa pemahaman yang digeluti, seperti hubungan keliru tentang pemamfaatan atau persahabatan, hubungan kekeluargaan penggunaan layanan bimbingan dan dan hubungan kemasyarakatan. ${ }^{3}$ konseling yang dipergunakan oleh Terjadinya Hubungan awal dalam beberapa kalangan baik kalangan proses konseling yaiitu konselor dengan akademisi maupun non akademisi. Oleh konseli dapat terjadi berupa hubungan sebab itu sebagai seorang Konselor/guru keterpaksaan atau hubungan suka rela, BK harus memiliki pemahaman tentang hubungan keterpaksaan disebabkan pengunaan kedua istilah tersebut, kapan karna Konselor melakukan pemanggilan kita melaksanakan upaya bimbingan dan terhadap konseli disebabkan karna kapan kita melaksanakan upaya kesalahan yang dilakukan oleh konseli konseling. tersebut, yang pada akhirnya konseli Konseling merupakan sebagai merasa terpaska datang menemui salah satu hubungan yang sifatnya Konselor. Selanjutnya hubungan membantu, dilihat dari strukturnya, sukarela antara Konselor dengan membantu dapat dibedakan atas konseli. Hubungan sukarela ini terjadi hubungan yang profesional dan karna keinginan konseli itu sendiri yang hubungan bukan professional. datang menemui konselor/guru BK Hubungan membantu yang bersifat dengan tujuan meminta bantuan untuk professional merupakan hubungan yang memecahkan permasalahan yang dilakukan oleh setidak-tidaknya dialami oleh konseli itu sendiri. Pada terdapat seorang tenaga profesional umumnya hubungan suka rela lebih yang membantu pihak lain, dan disukai, karena akan memudahkan pekerjaan tersebut dalam konteks terjadinya proses konseling lebih lanjut. sebagai profesi yang ditekuninya, seperti 
Sebenarnya apapun bentuk hubungan awal itu mau terpaksa atau suka rela, yang sangat berpengaruh adalah bagaimana seorang konselor/guru BK mampu mempengaruhi konseli dalam komunikasi konseling.

Konseling dijalankan dengan komunikasi, bisa juga dikatakan konseling adalah komunikasi. Bahkan keberhasilan konseling akan ditentukan oleh bagaimana konselor memiliki keterampilan komunikasi yang baik. Karna dengan adanya keterampilan komunikasi yang dimiliki oleh konselor akan mampu menginspirasi, memotivasi dan mengedukasi yang tidak lain tujuannya adalah tersolusinya masalah konseli. ${ }^{4} \quad$ Seorang konselor harus memiliki pengaruh serta mampu mempengaruhi, walaupun dalam prinsif konseling Konselor tidak boleh mempengaruhi konseli. Mempengaruhi konseli bukan berarti kita sebagai Konselor mengendalikan sepenuhnya diri konseli tersebut, yang tidak boleh dilakukan oleh Konselor adalah mempengaruhi keputusan yang diambil oleh konseli itu sendiri. ${ }^{5}$ Setiap keputusan yang pilih oleh konseli akan

\footnotetext{
${ }^{4}$ Afron Shoji, Hypnotic Counseling, ${ }^{4}$ Afron Shoji, Hypnotic
(Pekalongan; Shoji Media Sakti, 2018), hal. 14. ${ }^{5}$ Afron Shoji, Hypnotic Counseling,..., hal. 9.
}

dipertanggung jawabkan oleh konseli itu sendiri. Pada sejatinya dalam proses konseling yang baik adalah konselor memiliki pengaruh dan mampu mempengaruhi. Yang dilakukan oleh Konselor adalah mempengaruhi konseli agar merasa nyaman, percaya, dan yakin kepada Konselor, sehingga konseli terbuka serta leluasa dalam menceritakan permasalahannya. Kemudian yang sangat perlu dilakukan oleh konselor setelah mendengarkan permasalahan konseli adalah mempengaruhi konseli agar konseli mau melawan dirinya, mau mengatasi permasalahannya serta mau mengubah prinsif hidupnya dari masalah menjadi anugrah.

Menurut Arintoko, seorang konselor harus mampu menggali perasaan dan pikiran konseli. Proses penggalian ini membutuhkan sebuah tehnik khusus agar pertanyaan/ pernyataan yang dilontarkan konselor kepada konseli dapat menghipnosis konseli untuk semakin terbuka. ${ }^{6}$ Untuk itu Dalam proses komunikasi konseling terdapat dua jenis tehnik komunikasi yang harus dikuasai oleh seorang konselor diantaranya; komunikasi verbal

\footnotetext{
${ }^{6}$ Arintoko, Wawancara konseling di Sekolah, (Yogyakarta; Penerbit Andi, 2009), hal. 25.
} 
dan tehnik komunikasi non verbal. Prilaku verval adalah cara respon yang dilakukan oleh konselor kepada konseli dengan ucapan lisan, sedangkan prilaku non verbal adalah cara respon yang dilakukan oleh konselor kepada konseli dengan menggunakan bahasa tubuh (body language) atau dengan menggunakan bahasa isyarat, didalam komunikasi non verbal terdapat dua elemen bahasa tubuh yaitu pengiriman pesan dan penerimaan pesan. ${ }^{7}$ Prilaku non verbal muncul secara acak kadang diawal, pertengahan dan kadang juga diakhir, akan tetapi berada pada setiap elemen helping relationship. Artinya, konselor dan konseli akan selalu menghadirkan prilaku tersebut yang bersamaan dengan lisannya.

\section{B. Prinnsif-prinsif Hipnotic counseling yang harus dimiliki Konselor ${ }^{8}$ :}

1. Menciptakan kesan pertama yang baik

$$
\text { Kesan pertama adalah }
$$
segalanya. Orang jatuh hati pada pandangan pertama karena kesan pertama yang luar biasa. Jika pada kesan pertama konselor/guru BK

${ }^{7}$ Sofyan S. Willis, Konseling Individual Teori dan Pratek, (Bandung; Alfabeta, 2014), hlm 30

${ }^{8}$ Afron Shoji, Hypnotic Counseling..., 67 mampu membuat konseli merasa nyaman dan percaya, maka seterusnya konseli akan merasa nyaman dan percaya dengan konselor/guru BK. Jadi jika anda sebagai konselor/guru BK maka anda harus mampu menyakinkan pikiran dan perasaan pada kesan pertama. Adapun hal-hal harus dimiliki oleh konselor untuk membuat kesan pertama menjadi baik antara lain:

a. Good looking atau dengan kata lain enak dipandang. Inilah salah satu pilar untuk menciptakan kesan pertama dalam benak konseli. Seorang konselor harus memperhatikan penampilan serta kebersihan dirinya dari ujung rambut hingga ujung kaki, pastikan raut muka segar, rambut rapi, serta pakaian yang pantas. Konselor bukannya dituntut untuk berpenampilan mewah atau berpenampilan model artis, tapi konselor dituntut untuk pernampilan yang layak untuk dicontoh serta sesuai dengan keadaan konseli yang dihadapi, asalkan jangan sampai seorang konselor memiliki penampilan yang kusut kasat, hal tersebut 
sangat mempengaruhi pandangan konseli terhadap konselor.

b. Eksperesi, seorang konselor harus mampu menunjukkan eksperesi yang bersahabat, tatapan mata yang menunjukkan kalau anda siap dan tulus menerima konseli dengan apadanya bukan ada apanya serta siap membantu konseli melalui layanan bimbingan dan konseling.

c. Bahasa tubuh, seorang konselor harus mampu menggunakan bahasa tubuh yang baik pada saat menerima maupun pada saat proses konseling berjalan. Menurut Afron Shoji, bahasa yang tubuh yang baik dimulai dari hati dan pikiran. Seorang konselor yang percaya diri akan kelihatan dari bahasa tubuhnya bahwa dia sangat percaya diri sebaliknya konselor yang grogi akan kelihatan dari bahasa tubuhnya bahwa dia sedang grogi. Oleh sebab itu seorang konselor harus mampu menselaraskan hati dan pikirannya agar memiliki niat yang tulus, ihlas,dan merasa senang penuh suka cita dalam melayani konseli.

d. Dinamika batin, dimana seorang konselor/guru BK harus mampu memberikan perhatian pada batinnya sendiri, apakah batinnya sendiri sudah terlepas dari emosi negatif seperti perasaan kecewa, marah dan lainnya dan seorang konselor juga harus mampu melakukan komunikasi batin dengan konseli yaitu dengan pengucapan bahasa di dalam hati dengan rasa ihlas dan tulus pada saat menerima konseli.

2. Perasaan bahagia, apabila kita ingin membantu orang tenggelam maka kita harus mampu berenang dan apabila kita mau membuat orang bahagia maka kita sebagai konselor harus bahagia terlebih dahulu, oleh sebab itu seorang konselor/guru BK harus menciptakan perasaan bahagia terlebih dahulu sebelum memberikan layanan konseling dan pada saat pemberian layanan konseling kepada konseli secara tidak langsung 
konselor berbagi getaran bahagia kepada konseli.

3. Berpikir bijaksana, seorang konselor/guru BK hendaknya berpikir bijaksana, baik untuk kehidupan dirinya sendiri, maupun saat membantu orang lain dalam layanan bimbingan dan konseling. Karna dengan memiliki pikiran yang bijaksana adalah sebagai modal awal untuk menemukan solusi dari setiap masalah.

4. Sugesti makna hidup, seorang konselor/guru BK harus mampu memberikan sugesti makna hidup kepada dirinya maupun kepada konseli itu sendiri, dengan memberikan sugesti makna hidup sebagai langkah awal membuka pandangan konseli tentang bagaimana dia memandang hidup ini. Seperti Mensugesti bahwa hidup adalah anugrah atau hidup adalah perjuangan bukan hidup adalah masalah. Setelah konselor mampu memberikan sugesti makna hidup, maka akan mudah dalam menentukan apa yang menjadi fokus kehidupan konseli yang akan datang sehingga dengan mudah membantu konseli memecahkan permaslahannya.

5. Kritikan yang membangun, dalam proses konseling seorang konselor/guru BK sebisa mungkin menghindari melakukan kritikan kepada konseli meskipun tujuan anda memberikan kritikan itu baik. Karna kenyataannya tidak ada orang mau dikritik. Yang dilakukan oleh konselor/guru BK adalah memberikan penyataan dukungan atau pujian sehingga kenyamanan konseli tetap terjaga.

6. Kekuatan mata, dalam proses konseling kekuatan mata sangatlah penting, dengan kekuatan mata konselor bisa menunjukkan eksperesinya kepada konseli, seperti ekperesi rasa empati pada saat konseli menceritakan permasalahannya, yang sesuai dengan keadaan konseli yang sedang bercerita apakah suasana sedih atau suasana menangis. Tatapan mata juga dapat membuat 
konselor/guru BK memiliki dengan adanya bahasa, komunikasi wibawa, dengan adanya wibawa seseorang bisa dimengerti oleh orang lain. konselor akan memiliki Begitu juga dalam proses konseling, pengaruh serta mampu konseling bisa terlaksana dengan baik mempengaruhi konseli. Pada saat karna adanya komunikasi dengan konselor dengan konseli menggunakan bahasa yang baik. Namun melakukan kontak mata jangan dalam proses konseling hipnotik ada sampai konselor terlebih dahulu beberapa pola bahasa yang digunakan mengedipkan mata sebelum untuk mempengaruhi konseli konseli berkedip terlebih dahulu, diantaranya: ${ }^{9}$

apabila hal tersebut terjadi bisa jadi konselor tidak memiliki pengaruh kepada konseli.

7. Buang gadget anda, sebelum proses pelaksanaan konseling berlangsung sebaiknya konselor dan konseli menyepakati bersama bahwa masing-masing gadget dilepas sementara selama proses layanan konseling berlangsung, karna hal tersebut sangat mempengaruhi hasil dari layanan konseling dan bisa juga salah satu pihak merasa tidak perhatikan baik itu konselor maupun itu konseli.

\section{Pola bahasa hipnotik}

Bahasa digunakan untuk

\section{Menggunakan kata atau kalimat} yang memberdayakan

Kata atau kalimat memiliki kemampuan yang sangat dahsyat dalam mempengaruhi orang lain dan kata-kata juga bisa menjadi obat bagi orang lain. Dalam proses konseling seorang konselor/guru BK disarankan menggunakan kata atau kalimat yang memberdayakan. Pada saat seorang konseli menyatakan perasaannya dengan menggunakan pernyataan negatif, maka seorang konselor harus merespon konseli dengan menggunakan pernyataan/kalimat yang positif, apabila konselor/guru BK merespon konseli dengan menggunakan kalimat negatif, secara komunikasi, alat untuk berkomunikasi adalah bahasa baik bahasa secara

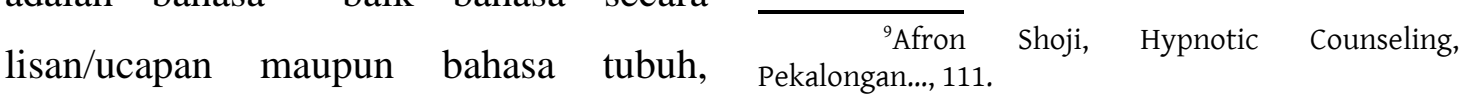


tidak langsung alam bawah sadar konseli akan berpengaruh.

Contoh: konseli menyatakan dirinya sedang sedih dikarenakan masalahnya maka respon konselor/guru BK dengan menggunakan kata atau kalimat yang memberdayakan seperti "kamu harus tenang dan bersabar setiap masalah pasti ada solusinya"

\section{Tehnik pola perbandingan}

Seorang konselor/guru BK dalam melaksanakan konseling sangat dianjurkan menggunakan pola perbandingan, dengan menggunakan pola perbandingan sangat mempengaruhi termotivasinya konseli kembali dalam menyelesaikan masalahnya sendiri. Yang pada awalnya konseli datang kepada konselor dengan merasa tidak berdaya, kemudian konselor/guru BK memberikan pola perbandingan, maka konseli akan memiliki semangat kembali dalam menyelesaikan masalahnya sendiri. Contoh kalimat pola perbandingan yang digunakan konselor/guru BK kepada konseli yang merasa tidak berdaya.

Pernyataan konselor : " tenang saja tidak hanya sendirian anda yang mengalami hal seperti itu melainkan banyak orang diluar sana dan mereka tetap menjalani hidupnya serta berusa menyelesaikan masalahnya sendiri, yang pada akhirnya mereka mampu menunjukkan dirinya sebagai orang yang sukses."

3. Antara saya-anda dan aku-kamu

Pada saat pelaksanaan konseling seorang konselor/guru BK harus mampu memilih kata yang pantas untuk menyatakan dirinya maupun kata yang pantas untuk menyatakan diri konseli itu sendiri, seperti penggunaan kata saya-anda, aku-kamu dan penyebutan nama. Istilah ini selalu digunakan dalam komunikasi konseling, tapi yang menjadi pertanyaan sudah sesuai tidak dengan kondisi konseli yang dihadapi, penggunaan istilah ini sangat berpengaruh sekali dalam membangun hubungan konselor dengan konseli khususnya pada hubungan komunikasi konseling. Kapan pantasnya konselor menyatakan saya dan aku kepada dirinya atau kapan pantasnya konselor menyatakan anda, kamu dan menyebut nama langsung kepada konseli, yang kesemuanya harus disesuaikan dengan siapa konseli yang kita layani baik dari usia, jabatan maupun status sosialnya. 
4. Tehnik perumpamaan

Tehnik perumpamaan merupakan pemberian gambaran kepada konseli tentang masalah yang sedang dihadapinya. Dengan tehnik perumpamaan konselor dengan mudah mempengaruhi konseli itu sendiri baik dalam mempengaruhi perasaanya maupun prinsif hidupnya. Contoh penerapan tehnik perumpamaan.

Pernyataan konseli : "hidup saya kok seperti ini setiap usaha yang saya jalankan selalu mendapat ujian yang pada akhirnya mengalami kegagalan, padahal saya sudah berusaha dan berdo'a".

Respon konselor : "apakah anda tahu sebuah batangan besi yang awalnya tidak ternilai, setelah melalui proses yang dilakukan oleh tukang besi, dibakar, diterpa kemudian dipahat yang pada akhirnya akan menjadi sebuah pisau yang tajam yang bisa berharga dan bermanfaat bagi orang lain."

\section{Kekuatan kutipan}

Konselor/guru BK dalam menyampaikan penjelasan kepada konseli tentang masalah yang sedang dihadapi konselor bisa menggunakan kekuatan kutipan. Dengan kekuatan kutipan ini bisa mempengaruhi konseli. Contoh ;

Konseli : Duh.. hidup saya kok sulit begini ya
Konselor : Saya pernah membaca kita suci Al-Qur'an menyatakan sesungguhnya bersama kesulitan pasti ada kemudahan.

\section{Tehnik-tehnik konseling}

1. Prilaku Attending

Attending merupakan keterampilan dasar yang harus dimiliki oleh seorang konselor, pada tahap ini konselor harus mampu memberikan rasa hormat yang baik kepada diri konseli. ${ }^{10}$ Apabila pada kesan pertama yang tidak baik maka tidak menutup kemungkinan kesan selanjutnya akan tidak baik juga. Prilaku attending juga dapat dikatakan sebagai penampilan konselor dalam menampakkan komponen-komponen prilaku verbal dan non verbal. ${ }^{11}$ Pada tahap ini konselor/guru BK dituntut memiliki keterampilan berkomunikasi melalui isyarat-isyarat verbal dan non verbal dan tidak kalah pentingnya juga konselor/guru BK harus memiliki penampilan yang enak dipandang (good looking) sehingga terbangun kepercayaan konseli kepada konselor

\footnotetext{
${ }^{10}$ Arif Ainur Rofiq, Keterampilan Komunikasi Konseling, (Bogor, PT. Grha Cipta Media, 2016), hlm. 02 ${ }^{11}$ Sofyan S. Wills, Konseling individual Teori dan Praktek, (Bandung, Alfabeta; 2004), hlm. 176.
} 
lebih baik. ${ }^{12}$ Adapun keterampilan Attending seperti; konselor menjawab salam konseli (verbal), langsung menjabat tangan konseli serta mempersilahkan konseli duduk (non verbal). Keterampilan-keterampilan attending yang lain meliputi: keterampilan bahasa tubuh, ekperesi wajah, dinamika batin serta membuat lingkungan yang nyaman, yang kesemuanya itu harus mampu ditampilkan oleh konselor untuk membuat kesan pertama yang baik.

1. Opening (pembukaan)

Pada tahap ini konselor/guru BK mulai membangun komunikasi awal, baik komunikasi verbal maupun non verbal, adapaun komunikasi verbal pada tahap ini mulai dari menayakan nama apabila masih belum kenal, kabar konseli serta kabar keluarga konseli dirumah, kemudian komunikasi non verbal bisa berupa ekperesi wajah serta bahasa tubuh.

2. Topik netral

Pada tahap topik netral, konselor mengajak konseli berbicara

${ }^{12}$ Richard Nelson Jones, Pengantar Keterampilan konseling, (Yogyakarta, Pustaka Pelajar: 2009), hal. 22. terkait dengan kegiatankegiatan yang dilakukan setiap harinya oleh konseli. Yang mana semua pembicaraan ini bertujuan membangun komunikasi, meningkatkan keakraban serta membuat konseli supaya tidak merasa kaku dalam berkomunikasi.

3. Peralihan topik netral ke permulaan konseling

Pada tahapan ini seorang konselor/guru BK harus memiliki keterampilan mengalihkan topik pembicaraan yang awalnya bersifat umum kemudian mengerucut ke hal yang lebih khusus, seperti pengalihan topik netral ke permulaan konseling.

4. Acceptance

Acceptance adalah teknik yang digunakan oleh konselor/guru BK untuk menunjukan penerimaan, rasa ingin tahu serta pemahaman terhadap hal-hal yang dikemukakan atau yang ceritakan oleh konseli itu sendiri. Pada tahap ini konselor menggunakan bahasa verval dan non verbal, bahasa verval seperti merespon konseli dengan kata- 
kata rasa ingin tahu lebih lanjut tentang cerita konseli itu sendiri, adapun komunikasi non verval bisa digunakan dengan bahasa tubuh seperti anggukan kepala.

5. Restatement (Pengulangan) Restatement adalah teknik yang digunakan konselor/guru BK untuk mengulangi atau menyatakan kembali pernyataan konseli baik sebagian maupun keseluruhan yang dianggap penting, yang digunakan untuk merespon konseli sekaligus sebagai bentuk pemahaman konselor/guru BK terhadap masalah yang diceritakan oleh konseli itu sendiri.

6. Structuring (Pembatasan)

Structuring adalah teknik yang digunakan oleh konselor/guru BK untuk memberikan batasanbatasan ruanglingkup konseling, agar proses konseling berjalan dengan baik serta tercapai apa yang menjadi tujuan konseling itu sendiri. Adapun jenis-jenis structuring :

a. Stucturing time limit (Pembatasan waktu), dalam konseling pembatasan waktu itu sangat penting, karna dengan adanya batasan waktu, waktu yang sudah dipersiapkan dapat dimanfaatkan dengan seefektif mungkin dan tidak molor.

b. Stucturing role limit (Pembatasan peran), pematasan peran sangat penting dipaparkan oleh konselor kepada konseli, agar tidak terjadi kesalah pahaman. Dengan adanya pembatasan peran konseli akan mengerti peran dan tugas seorang konselor/guru BK itu sendiri.

c. Structuring problem limit (pembatasan masalah). Pembatasan masalah juga tidak kalah pentingnya perlu dilakukan oleh konselor, yang kadang kala konseli menceritakan masalahnya dengan panjang lebar yang pada akhirnya konseli tidak mengetahui yang mana sebagai sumber masalah dan yang mana dampak masalah itu sendiri, sehingga dalam 
hal ini konselor perlu membatasi masalah yang akan dibahas, yang tentunya konseli harus memilih masalah yang terpenting untuk dibahas terlebih dahulu.

d. Structuring action limit (Pembatasan tindakan), terkait dengan pembatasan tindakan sangat perlu sekali dipaparkan oleh konselor kepada konseli baik aturan yang terdapat dalam ruangan konseling maupun aturan yang ada dalam bimbingan dan konseling, sehingga konseli mampu mengatur sikap dan tingkah lakunya selama proses konseling berlangsung serta meningkatkan rasa percaya konseli kepada konselor.

7. Reflection of feeling (pemantulan perasaan), adalah teknik yang digunakan oleh konselor/guru BK untuk memantulkan perasaan/sikap yang terkandung di balik pernyataan konseli. Pada tahap ini konselor harus mampu menggunakan kata atau kalimat yang bisa memberdayakan yaitu dengan merespon konseli dengan kata atau kalimat positif. Dalam hal ini konselor/guru BK bisa menggunakan pola bahasa hipnotik dengan menggunakan pihan kata dan pola kalimat yang memberdayakan sebagaimana yang tertera diatas. ${ }^{13}$

8. Rejection (penolakan)

Tehnik rejection digunakan oleh konselor/guru BK pada saat konseli merasa kebingungan dengan tindakan yang akan diambil untuk mengatasi permasalahannya, dengan kebingunggannya konseli akan mengambil sikap yang negatif . Dalam hal ini konselor/guru BK sangat berperan aktif dalam memberikan pertimbangan atau mencegah konseli untuk tidak mengambil sikap seperti itu. konselor/guru BK memberikan gambaran mengenai dampak dan mamfaat terhadap sikap negatif yang akan dilakukan oleh konseli itu sendiri. pada tahap ini konselor/guru BK bisa juga menggunakan pola bahasa

${ }^{13}$ Afron Shoji, Hypnotic Counseling, Pekalongan..., hal. 112. 
counseling hypnotic yaitu dengan menggunakan tehnik perumpamaan sebagaimana yang tertera diatas.

9. Silence (diam)

Tehnik diam adalah sangat penting dalam proses konseling, diam bukan berarti tidak ada komunikasi akan tetapi komunikasi bisa dilakukan melalui prilaku non verbal. ${ }^{14}$ Tahapan bertujuan memberikan kesempatan konseli untuk berpikir. Dalam tahapan ini konselor/guru BK bisa juga menggunakan prinsif dinamika batin yaitu komunikasi melalui batin.

10. Sharing of experience (berbagi pengalaman)

Pada tahap ini konselor melakukan berbagi pengalaman terkait dengan pemecahan masalah konseli itu sendiri yang hampir mirip dengan masalah yang sedang dialami, atau bisa juga seorang konselor menggunakan tehnik pola perbandingan sebagaimana yang

${ }^{14}$ Sofyan S. Wills, Konseling individual Teori dan Praktek..., 176 terdapat pada pola bahasa hipnotik counseling diatas.

11. Clarification

Clarification adalah teknik yang digunakan untuk mengungkapkan kembali isi pernyataan konseli, dimana konseli memandang kedua hal sama persis, dalam hal ini konselor/guru BK merespon konseli dengan menggunakan kata-kata baru dan segar. ${ }^{15}$ Seperti, konselor: "Dengan kata lain, Anda menyamakan Ari dengan Andi".

12. Reassurance (penguatan) Pada tahap ini konselor/guru BK memberikan penguatan terhadap pernyataan atau pilihan konseli terkait dengan sikap yang akan diambil konseli sebagai solusi untuk mengatasi permasalahannya. Seperti, Konselor : Bagus itu nak, semoga anda berhasil dalam

13. Summary

Ringkasan/kesimpulan ) 
al-Tazkiah, Volume 8 No. 1, Juni 2019

Summary
ketrampilan/teknik yalah
digunakan konselor/guru BK
untuk menyimpulkan atau
ringkasan mengenai pernyatan
atau pilihan yang akan diambil
oleh konseli terkait dengan
menyelesaian masalah konseli itu
sendiri. ${ }^{16}$.
Seperti, Konselor : Baiklah, di sini
kita bisa simpulkan anda
memiliki masalah ingin
melanjutkan sekolah,biaya
tidak ada dan saudara tidak
mau peduli Sekarang yang
akan anda lakukan
mendekati saudara anda
supaya dia mau peduli
dengan keadaan anda.

14. Termination (Pengakhiran)

Termination

adalah

ketrampilan/teknik yang

digunakan konselor/guru BK untuk mengakhiri komunikasi konseling, baik mengakhiri untuk dilanjutkan pada pertemuan berikutnya maupun mengakhiri karena komunikasi konseling betul-betul telah berekhir.

Seperti, Konselor : Baiklah waktu kita sudah habis, semoga apa yang anda dapatkan disini bermanfaat bagi anda dan imfprmasi selanjutna tunggu dari anda.

\section{E. Penutup}

Generasi milenial memiliki karakter unik berdasarkan wilayah dan kondisi sosial-ekonomi. Salah satu ciri utama generasi milenial ditandai oleh peningkatan penggunaan dan keakraban dengan komunikasi, media, dan teknologi digital. Karena dibesarkan oleh kemajuan teknologi, generasi milenial memiliki ciri-ciri kreatif, informatif, mempunyai passion dan produktif $^{17}$.

Pelaksanaan konseling tidak bisa dilaksanakan oleh sembarangan orang melainkan hanya bisa dilaksanakan oleh orang-orang yang sudah memiliki kualifikasi akademik minimal S1 dalam bidang bimbingan dan konseling serta memiliki kompetensi dalam bidang bimbingan dan konselung. Adapun kompetensi tersebut salah satunya yaitu bagaimana seorang konselor/guru BK memiliki keterampilan dalam berkomunikasi, khsusunya keterampilan dalam komunikasi konseling.

Selain memiliki keterampilan komunikasi konseling seorang konselor/guru BK harus menguasai 
tehnik-tehnik dalam pelaksanaan konseling individual, yang mana tehniktehnik tersebut akan mengatur alur daripada kelanjutan proses konseling. Apabila seorang konselor/guru BK tidak menguasai tehnik-tehnik konseling secara umum bisa jadi proses konseling akan beralih menjadi proses bimbingan dan bukan lagi proses konseling.

Dan keberhasilan konseling selain dipengaruhi oleh bagaimana konselor/guru BK menguasai tehniktehnik konseling yang tidak kalah penting juga bagaimana seorang konselor mampu memberi pengaruh kepada konseli yang dilayaninya. Dalam proses konseling pengaruh konselor terhadap konseli sangatlah penting karna dengan proses mempengaruhi konselor akan mendapat pengakuan yang baik dari konseli serta konselor/guru BK akan mudah dalam memberikan bantuan kepada konseli yang dilayaninya.

\section{Daftar Pustaka}

Arif Ainur Rofiq, Keterampilan Komunikasi Konseling, (Bogor, PT. Grha Cipta Media: 2016)

Afron Shoji, Hypnotic Counseling, (Pekalongan, Shoji Media Sakti: 2018)

Arintoko, Wawancara Konseling di Sekolah, (Yogyakarta, Penerbit Andi: 2009)

Kathryn Geldard \& David Geldard, Membantu Memevahkan Masalah Orang Lain DenganTehnik Konseling, (Yogyakarta, PustakaPelajar: 2008) Latipun, Psikologi Konseling, (Malang, UMM Pres: 2011)

Richard Nelson Jones, Pengantar Keterampilan konseling, (Yogyakarta, Pustaka Pelajar: 2009)

Sofyan S. Willis, Konseling Individual Teori dan Pratek, (Bandung, Alfabeta: 2014)

Permendikbud Nomor 111 Tahun 2014 Tentang Bimbingan dan Konseling Pada Pendidikan Dasar dan Menengah.

Permendiknas Nomor 27 Tahun 2008 Tentang Standar Kualifikasi Akademik dan Kompetensi Konselor. 